\title{
Asymmetric palatine tonsil in a pediatric patient: Is it always a malignant neoplasm?
}

\author{
Alejandro Azamar ${ }^{1 *}$, Carlos De la Torre-González¹, Luis Juárez-Villegas², Stanislaw Sadowinski-Pine ${ }^{3}$, and \\ Hiram Álvarez-Neri' \\ ${ }^{1}$ Departamento de Otorrinolaringología Pediátrica; ${ }^{2}$ Departamento de Oncología Médica; ${ }^{3}$ Departamento de Anatomía Patológica. Hospital Infantil \\ de México Federico Gómez, Mexico City, Mexico
}

\begin{abstract}
Background: A relatively frequent clinical finding in children is an asymmetric tonsil, which can have multiple etiological possibilities, including a malignant disease. The clinical finding of tonsillar asymmetry is found in approximately $2 \%$ of the pediatric population. The incidence of malignancy in the tonsils is low, estimated as 2.5 cases per 10,000 tonsillectomies. Due to its low incidence, the diagnostic tonsillectomy is not justified when tonsillar asymmetry is the only clinical finding. However, it is necessary to identify the critical clinical findings of high suspicion of malignancy that justify the performance of immediate surgery in the pediatric population. Case report: We present the case of a 10-year-old male patient. Four months before admission, the patient started with pharyngodynia and dysphagia, treated as recurrent tonsillitis. Due to exacerbation of the symptoms, orthopnea, and B symptoms, the patient came to consultation; tonsillar asymmetry was observed predominantly on the left side, with exophytic lesions extending to the hypopharynx. We decided to perform an incisional biopsy and tracheostomy due to compromised airway; histopathological diagnosis came back as B-cell lymphoma. Conclusions: Given the clinical scenario of recurrent tonsillitis, unresponsive to conventional medical treatment with antibiotics, tonsillar asymmetry with suspicious tonsillar appearance accompanied by symptoms such as fever, diaphoresis, cervical lymphadenopathy, obstructive symptoms in a pediatric patient, it is necessary to refer the patient to the specialist for timely diagnosis and treatment.
\end{abstract}

Keywords: Pediatric asymmetric tonsil. Lymphoma. Palatine tumors.

\section{Asimetría amigdalina en pediatría: ¿cuándo sospechar malignidad?}

\section{Resumen}

Introducción: La asimetría amigdalina es un hallazgo clínico relativamente frecuente en los niños. Se ha reportado en el $2 \%$ de la población pediátrica e incluye múltiples etiologías, entre ellas enfermedad maligna. La incidencia de malignidad es baja: se estima en 2.5 casos por cada 10,000 amigdalectomías. Por tal motivo, cuando se observa asimetría amigdalina como único hallazgo en la exploración física no se justifica la amigdalectomía con fines diagnósticos. Sin embargo, la incertidumbre de malignidad en el médico y en el paciente obliga a considerar los datos clínicos que permitan sospecharla y justificar la intervención quirúrgica. Caso clínico: Se presenta el caso de un paciente de sexo masculino de 10 años. Inició su padecimiento 4 meses previos a su ingreso hospitalario con faringodinia y disfagia, que fueron diagnosticadas y tratadas

Correspondence:

${ }^{*}$ Alejandro Azamar

E-mail: alejandro_azamar@hotmail.com
Date of reception: $30-09-2020$

Date of acceptance: $20-11-2020$

DOI: 10.24875/BMHIM.20000309
Available online: 17-09-2021

Bol Med Hosp Infant Mex. 2021;78(5):461-466

www.bmhim.com

1665-1146/C 2020 Hospital Infantil de México Federico Gómez. Published by Permanyer. This is an open access article under the CC BY-NC-ND license (http://creativecommons.org/licenses/by-nc-nd/4.0/). 
como amigdalitis recurrente. Acudió al hospital por agudización de los síntomas, evolucionando con ortopnea y síntomas $B$. En la exploración física se apreció asimetría amigdalina con aumento de volumen en la amígala izquierda extendida hasta la hipofaringe. Se decidió realizar una biopsia incisional y traqueostomía por compromiso respiratorio. El diagnóstico histopatológico fue linfoma de células B. Conclusiones: Ante un paciente pediátrico con amigdalitis recurrente, que no cede al tratamiento médico convencional y presenta asimetría amigdalina con aspecto sospechoso, acompañada de síntomas como fiebre, diaforesis, adenopatías cervicales y síntomas obstructivos, se deberá referir con el especialista para su diagnóstico y tratamiento oportunos.

Palabras clave: Asimetría amigdalina pediátrica. Linfoma. Tumor amigdalino.

\section{Introduction}

In most children, tonsillar asymmetry (TA) is secondary to benign hyperplasia or a false appreciation of increased volume due to a difference in tonsillar fossa depth. However, other causes have been reported (Table 1). A low incidence of malignancy is estimated: 2.5 cases per 10,000 tonsillectomies ${ }^{1}$. However, the possibility of a malignant tumor should be considered when evaluating any child with asymmetric tonsils. Among the malignant pathologies of Waldeyer's ring, the most frequent is B-cell non-Hodgkin's lymphoma $(\mathrm{NHL})$, which predominates in males $(2: 1 \text { ratio })^{1-3}$.

Despite their rarity, malignant neoplasms of Waldeyer's ring are severe diseases in which timely diagnosis and treatment are essential for the outcome.

TA suggests malignancy when there is rapid, unilateral tonsillar growth associated with changes in the appearance of the mucosa (altered color, visible lesion), cervical adenopathy, or hepatosplenomegaly 4 . TA of malignant etiology is rarely asymptomatic ${ }^{5}$. It may be accompanied by constitutional symptoms, such as weight loss, fever, and night sweats. It may manifest with ipsilateral odynophagia or otalgia, dysphagia, recurrent tonsillitis, snoring, and apnea.

Patients with tonsillar lymphoma have TA in $73 \%$ of cases, cervical lymphadenopathy in $30 \%$, and B symptoms in $16 \%^{5}$.

Symptoms may also vary according to age. For example, de Carvalho et al. ${ }^{6}$ reported the most common age-related clinical data in a series of 53 patients with tonsillar lymphoma. In children < 5 years of age, it was snoring; in the group of 6-10 years of age, it was lymphadenopathy, and in adolescents, it was dysphagia. Regardless of age, the most common histopathologic diagnosis was Burkitt's lymphoma, followed by B-cell lymphoma.

An epidemiological study in Turkey showed that 1.7\% of the healthy pediatric population, aged 4 to 17 years, presented $\mathrm{TA}^{\mathrm{T}}$. Considering that lymphoma is the third most common malignant disease in childhood, and $15 \%$ of head and neck lymphomas manifest in the tonsils, it is estimated that less than 30 of 210,000 children with TA per year may have a histopathologic diagnosis of lymphoma. With this incidence, it can be concluded that, although TA is relatively frequent in the pediatric population, it is unlikely that the enlargement is caused by lymphoma ${ }^{7-9}$.

Due to the low incidence of this malignant disease in pediatric patients with $T A$, diagnostic tonsillectomy is not indicated in all patients who present exclusively with this clinical finding. Therefore, it is essential to identify clinical data to justify it.

We describe the clinical case of a patient with B-cell lymphoma affecting the palatine tonsils and highlight the signs and symptoms of suspected malignancy that will allow the first contact physician to make an early and timely referral to a specialist.

\section{Clinical case}

We describe the case of a 10-year-and-10-month old male patient from Oaxaca, Mexico, with no relevant antecedents. Four months before hospital admission, odynophagia and pharyngodynia began. A private physician managed the patient with multiple antibiotic regimens for recurrent pharyngotonsillitis without improvement. A month before hospitalization, nocturnal fever and sweating were reported, and weight loss of $5 \mathrm{~kg}$ in a month. Due to exacerbation of symptoms and the presence of left earache, dysphagia, and orthopnea, the patient attended the emergency department.

The physical examination showed a conscious, oriented, irritable, pale, dehydrated patient, with dysphagia and hypersalivation, orthopnea, without audible stridor at a distance. The otorhinolaryngological examination reported bilateral otoscopy without alterations, normal anterior rhinoscopy, oral cavity with TA described as grade IV, verrucous, pedunculated left palatine tonsil, and right intravelic tonsil with normal characteristics (Figure 1). The neck had no palpable nodes.

Blood count on admission was normal. 


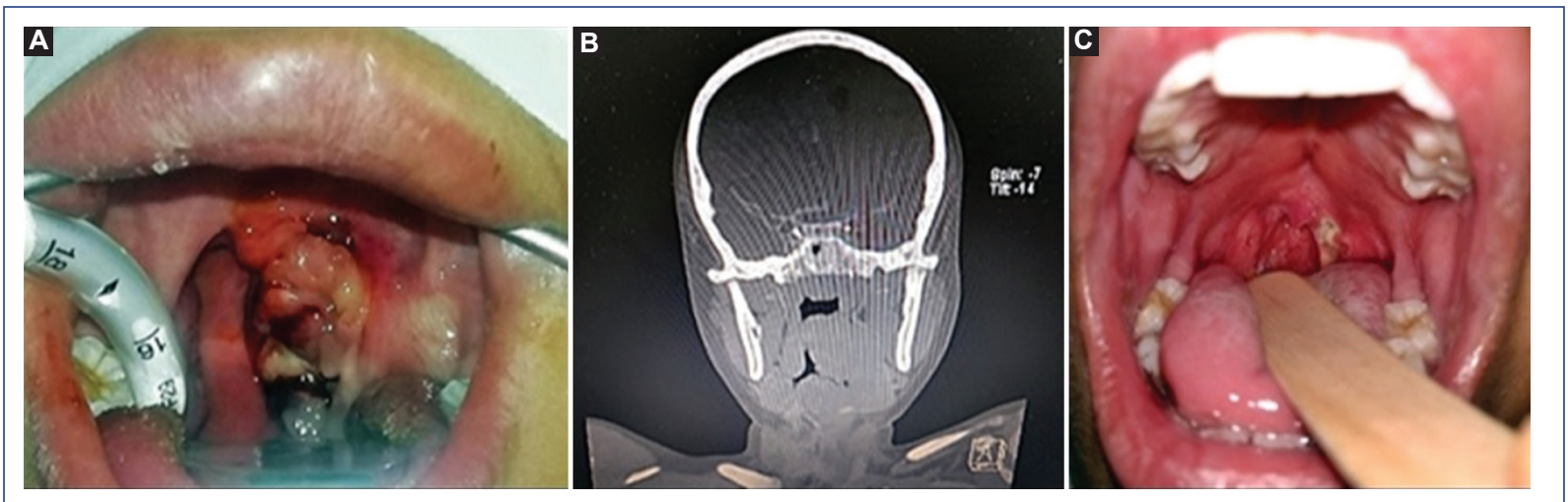

Figure 1. A: left tonsillar asymmetry, pedunculated, irregular borders, normal contralateral tonsil. B: a coronal tomographic section with contrast shows an isodense volume increase in soft tissues involving the left palatine tonsil and left peritonsillar space extending to the hypopharynx. C: a substantial decrease of the tumor is observed after the surgical procedure and one week after intravenous chemotherapy.

Table 1. Malignant and nonmalignant diagnostic possibilities of tonsillar asymmetry

\begin{tabular}{|l|l|}
\hline Nonmalignant causes & Malignant causes \\
\hline Actinomycosis & Non-Hodgkin's lymphoma \\
\hline Lymphoid hyperplasia & Rhabdomyosarcoma \\
\hline Papillary hyperplasia & Squamous cell carcinoma \\
\hline Recurrent infections & \\
\hline Respiratory allergy & \\
\hline Human papillomavirus infection & \\
\hline Peritonsillar abscess & \\
\hline
\end{tabular}

The simple and contrasted tomography of the head, neck, and mediastinum showed an increase in the volume of peritonsillar and left parapharyngeal spaces, with slight and homogeneous enhancement to the contrast medium and extension to the hypopharynx and supraglottis, causing displacement of the airway to the right; mediastinum apparently without lesions (Figure 1).

Due to the extension of the tumor into deep spaces in the neck, an incisional biopsy was performed, resecting a lobulated area of the left tonsil (approximately $1 \mathrm{~cm}$ in diameter), without observing profuse bleeding or other alterations. It was complemented with resection of the tumor in the hypopharynx and supraglottis to free the airway (Figure 2). An intraoperative histopathological study was requested, reporting suspicion of malignancy, possible rhabdomyosarcoma. Due to the obstruction of the airway caused by the tumor, a tracheostomy was performed without complications.

The definitive histopathological report was diffuse large B cell lymphoma (Figure 3), with immunohistochemistry positive for CD20, CD45, CD79, BCL6, and MUM1 (Figure 4).

The oncology service evaluated the patient and decided to take bone marrow and cerebrospinal fluid aspirates with a negative report for neoplastic cells. Therefore, the patient was classified as stage II.

The oncology treatment began based on the Lymphoma Malignancy B protocol (LMB-96 group B) the day after surgery: prephase (COP): vincristine (1.5 mg/ $/ \mathrm{m}^{2} /$ dose), cyclophosphamide ( $300 \mathrm{mg} / \mathrm{m}^{2} /$ day), prednisone $\left(60 \mathrm{mg} / \mathrm{m}^{2} /\right.$ day). Ten days after surgery, the COPAD M1 protocol was started: vincristine $\left(2 \mathrm{mg} / \mathrm{m}^{2} /\right.$ dose), methotrexate (3 $\mathrm{g} / \mathrm{m}^{2} /$ dose), cyclophosphamide (250 $\mathrm{mg} / \mathrm{m}^{2} / \mathrm{dose}$ ), doxorubicin $\left(60 \mathrm{mg} / \mathrm{m}^{2} /\right.$ dose), prednisone $\left(60 \mathrm{mg} / \mathrm{m}^{2} / \mathrm{day}\right)$.

After six complete cycles of chemotherapy, the patient is currently under surveillance since September 2019.

\section{Discussion}

TA is a relatively frequent clinical finding in the pediatric population. It is estimated that $41 \%$ of patients diagnosed with tonsil lymphoma are misdiagnosed and treated with courses of antibiotics that delay proper diagnosis and treatment ${ }^{10}$.

In the presence of TA, a study protocol should be initiated, including Doppler ultrasound in search of lymphadenopathy, trying to differentiate inflammatory 


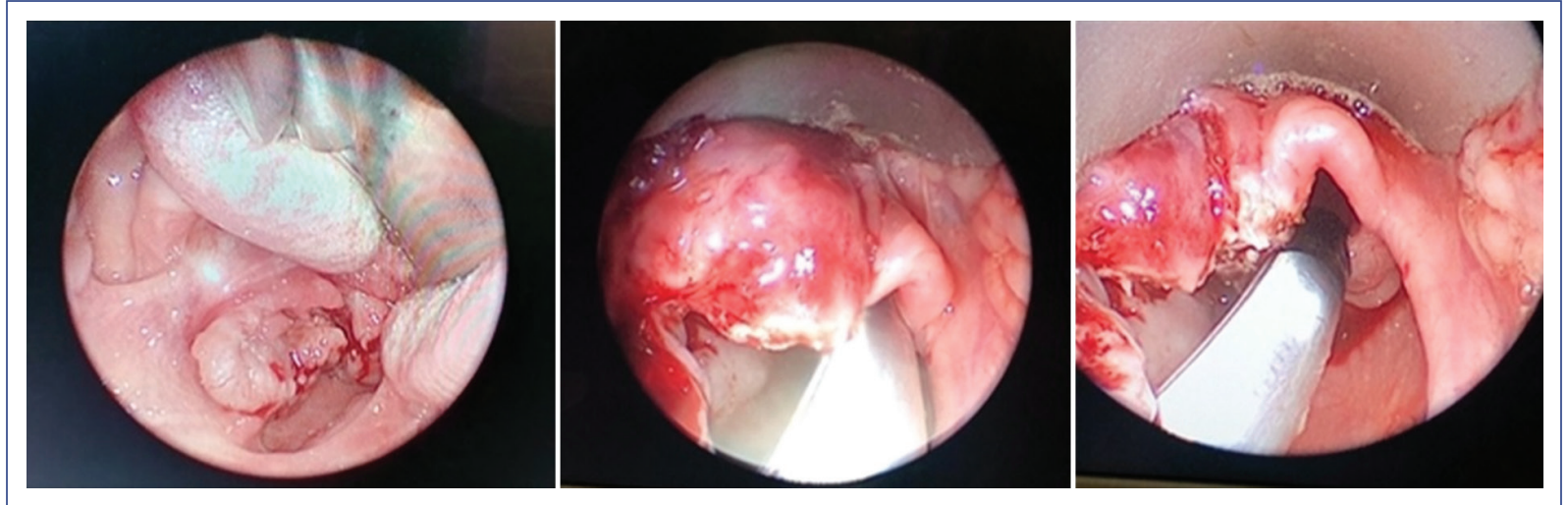

Figure 2. Photographic sequence of direct laryngoscopy before and after intubation, showing the difficult airway with loss of laryngeal anatomy and significant displacement of the airway to the right side. The image on the right shows a supraglottic tumor after incisional biopsy, with greater delineation of the epiglottis and wider glottic space.

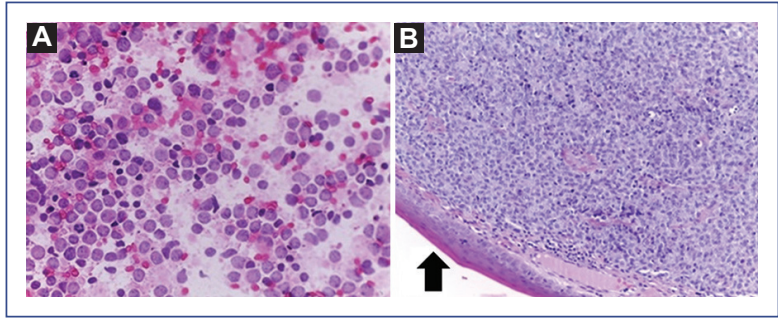

Figure 3. A: impression of the tumor, showing round neoplastic cells of homogeneous size and shape, with scant eosinophilic cytoplasm, the nucleus with fine chromatin, and some with an apparent nucleolus (Hematoxylin-eosin staining, 400x). B: histologic section of the neoplasm with homogeneous and monotonous cellularity of medium-sized cells growing below the tonsillar mucosa (arrow), round cell neoplasm, nuclei with granular and homogeneous chromatin, moderate mitotic activity (Hematoxylin-eosin staining, 200x).

reactive lymph nodes from those suspicious for malignancy ${ }^{11}$.

Most TAs are benign or are falsely perceived due to increased volume attributable to the difference in the tonsillar fossa's depth ${ }^{9,10}$. Other causes of TA are recurrent tonsillitis, chronic infections (tuberculosis, actinomycosis), granulomatous diseases (sarcoidosis), and benign tumors (papillomas) ${ }^{5,12}$.

The relationship of Actinomyces colonization with chronic tonsillar growth has been described ${ }^{8,12,13}$. In a prospective, comparative study (children with obstruction vs. recurrent infection) that included 90 children who underwent adenotonsillectomy, Kutluhan $\mathrm{A}$ et al. demonstrated the presence of Actinomyces in greater

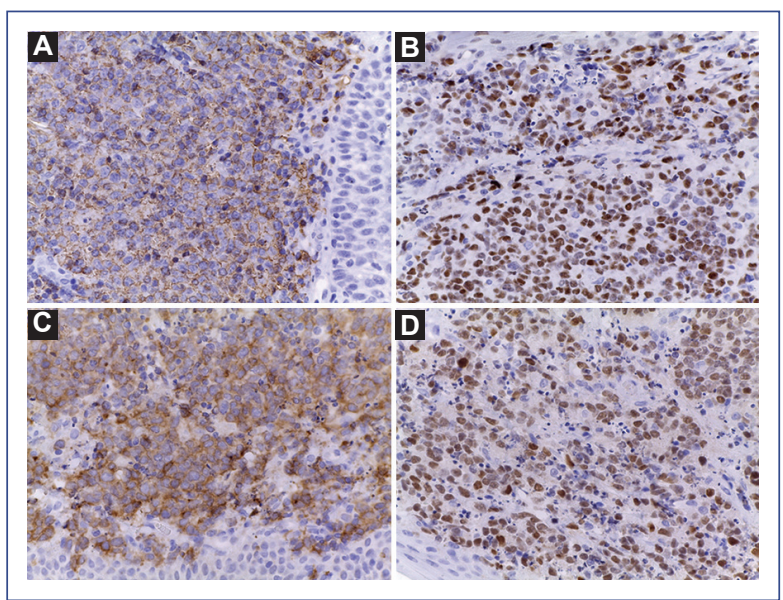

Figure 4. A: CD20 cytoplasmic expression pattern in neoplastic cells below the tonsillar mucosa, 400x. B: BCL6 nuclear expression in the neoplastic cells from the tumor lymphoid extirpation, 200x. C: CD79 $\alpha$ expression in the cytoplasm of neoplastic cells of lymphoid morphology of the tumor growing under the tonsillar mucosa, 400x. D: MUM1 nuclear expression in $85 \%$ of the neoplastic cells of the tonsillar lymphoma, 200x.

quantity in the tonsillar tissue of patients with obstructive symptoms compared to patients with recurrent tonsillitis $(p<0.001)$. Furthermore, the tonsillar volume was more significant in those with Actinomyces compared to those non-colonized $(p<0.001)$. Despite these findings, the mechanism by which Actinomyces colonization influences tonsillar volume remains unclear $^{12}$.

Since human papillomavirus (HPV) has been associated with carcinoma of the larynx and oral cavity, multiple studies have confirmed its role as an etiologic 
factor in other tumors of the upper airway and upper digestive tract. Tonsillar carcinoma has a strong association with HPV. Its primary relationship is with epidermoid carcinoma of the tonsil. Together with alcoholism and smoking, they are the main risk factors for its development. In the United States, squamous cell carcinoma represents $15-23 \%$ of head and neck tumors occurring mainly in adults.

Conversely, the information is scarce and controversial in children. Some reports show that HPV is present in palatine tonsils in $0-21 \%$ of children, without currently demonstrating its association with childhood cancer $^{13,14}$. Malignant neoplasms of the palatine tonsil can manifest clinically by $\mathrm{TA}$, dysphagia, otalgia, and verrucous lesions ${ }^{15}$.

The differential diagnosis of TA should include peritonsillar abscess, which represents $30-49 \%$ of neck abscesses in children. In these cases, symptoms such as trismus, tonsillar asymmetry, uvula deviation, dysphagia, guttural voice, fever, malaise, among others, are observed and always occur after poorly treated pharyngotonsillitis.

TA requires clinical diagnosis and imaging studies such as neck ultrasound and simple and contrasted computed tomography ${ }^{16}$.

Regardless of age, lymphoma is the most common malignant tonsillar tumor, followed by squamous cell carcinoma. The palatine tonsils are the most frequent site of extranodal non-Hodgkin's lymphoma ${ }^{9}$. The most common subtypes in pediatrics are Burkitt's lymphoma and large cell and B-cell lymphoblastic lymphoma, and their prevalence varies according to geographic region ${ }^{5}$.

As tonsillar lymphoma proliferates rapidly (an average period of 6 weeks), tonsillar growth that remains prolonged is unlikely to correspond to malignant disease, despite the existence of $\mathrm{TA}^{8}$.

According to Guimaraes et al., $88 \%$ of patients with tonsillar lymphoma present clinical data suggestive of malignancy, and $73 \%$ manifest $\mathrm{TA}^{5}$.

Several studies highlight the possibility of maintaining expectant management in TA cases and suggest performing tonsillectomy when there is a high possibility of malignancy ${ }^{8}$. The most frequent clinical data that suggest malignancy are concomitant lymphadenopathy and the aspect of the palatine tonsil ${ }^{5,9}$. Although the "suspicious appearance" may be subjective, ulcerations, exophytic projections, friable or verrucous lesions, tissue necrosis, and involvement of the soft palate or lateral pharyngeal wall are commonly described ${ }^{5}$.

Tonsillectomy is one of the most frequently performed surgeries in children. Most studies conclude that diagnostic tonsillectomy is indicated in children with significant asymmetric tonsillar hypertrophy when there is recent or progressive tonsillar enlargement, unusual appearance (color or lesion), or association with cervical adenopathy or hepatosplenomegaly with or with no constitutional symptoms $s^{1,5}$. If malignancy is suspected, tonsillectomy should be performed urgently for histopathological and immunohistochemical evaluation ${ }^{8}$.

On the contrary, rigorous follow-up for 6 weeks is suggested in those children with mild, asymptomatic TA, without other indications for surgery (such as recurrent tonsillitis or respiratory obstruction) or associated risk factors ${ }^{1,3}$.

In the case described here, the presence of asymmetric tonsillar hypertrophy with the appearance of exophytic projections, fever, nocturnal diaphoresis, aggravation of dysphagia, and orthopnea were the specific signs that led to suspect malignant disease. The definitive diagnosis should be histopathological by biopsy through tonsillectomy and not by needle puncture-aspiration due to the severe consequences of a false negative ${ }^{3,17}$.

In general, the biopsy should include the entire tonsil. However, the surgical planes may be so altered that complete tonsillectomy is not possible in some patients. It is crucial to obtain a large specimen in these cases, as it is sometimes difficult to distinguish between lymphoma and another malignant tumor ${ }^{17}$.

In our case, the biopsy was incisional due to infiltration of the parapharyngeal space; the tumor portion in the hypopharynx and supraglottis was almost completely removed.

CT scans are important to delimit tumor extension, and cerebrospinal fluid and bone marrow studies are essential to determine the patient's staging. On that basis, it would be possible to design the treatment and establish the prognosis ${ }^{6}$.

Lymphoma is a chemosensitive tumor. Therefore, treatment is based on combined chemotherapy with cyclophosphamide, doxorubicin, vincristine, dexamethasone, methotrexate, cytarabine, and rituximab, intravenous and intrathecal ${ }^{6,16}$. Prognosis depends on the extent of the disease, the histologic subtype, and the initial response to treatment ${ }^{5}$. Survival is estimated to be $90 \%$ for stage I patients and about $20 \%$ for stage IV patients ${ }^{5,9}$. Fortunately, tonsillar lymphomas tend to be well localized and, therefore, are associated with good outcomes ${ }^{17,18}$.

In the presence of TA with a suspicious appearance, accompanied by fever, diaphoresis, cervical lymphadenopathy, and obstructive symptoms, it is essential to 
refer the patient to a specialist to clarify the diagnosis and provide timely treatment.

\section{Ethical disclosures}

Protection of human and animal subjects. The authors declare that no experiments were performed on humans or animals for this study.

Confidentiality of data. The authors declare that they have followed the protocols of their work center on patient data publication.

Right to privacy and informed consent. The authors have obtained the written informed consent of the patients or subjects mentioned in the article. The corresponding author has this document.

\section{Conflicts of interest}

The authors declare no conflict of interest.

\section{Funding}

None.

\section{References}

1. Cuestas G, Martínez Font A, Demarchi MV, Martínez Corvalán MP García Rivello H, Morandi A, et al. Linfoma de amígdala en niño con asimetría tonsilar. Caso clínico. Arch Argent Pediatr. 2015;113:e219-e222.

2. Guimaraes AC, de Carvalho GM, Gusmao RJ. Tonsillar lymphoma in children with unilateral tonsilar enlargement. Rev Paul Pediatr. 2012;30:288-91.
3. Harley EH. Asymmetric tonsil size in children. Arch Otolaryngol Head Neck Surg. 2002;128:767-9.

4. Van Lierop AC, Prescott CAJ, Fagan JJ, Sinclair-Smith CC. Is diagnostic tonsillectomy indicated in all children with asymmetrically enlarged tonsiIs? S Afr Med J. 2007;97:367-70.

5. Guimaraes AC, de Carvalho GM, Bento LR, Correa C, Gusmao RJ. Clinical manifestations in children with tonsilar lymphoma: a systematic review. Crit Rev Oncol Hematol. 2014;90:146-51.

6. de Carvalho GM, Pauna HF, Crespo AN, Gusmao AR, Guimaraes AC. Tonsillar lymphoma in children according to age group: a systematic review. Iran J Otorhilaryngol. 2018;30:69-75.

7. Akcay A, Kara CO, Dagdeviren E, Zencir M. Variation in tonsil size in 4- to 17-year-old schoolchildren. J Otolaryngol. 2006;35:270-4.

8. Jones GH, Burnside G, McPartland J, Markey A, Fallon M, De S. Is tonsillectomy mandatory for asymmetric tonsils in children? A review of our diagnostic tonsillectomy practice and the literature. Int $\mathrm{J}$ Pediatr Otorhinolaryngol. 2018;110:57-60.

9. Silva TD, Ferreira CB, Leite GB, de Menezes Pontes JR, Antunes HS. Oral manifestations of lymphoma: a systematic review. Ecancermedicalscience. 2016,10:665.

10. Tobias-Gómez S, Palomar-Asenjo V, Borràs-Perera M, Pérez-Hernández I, Ruiz Giner A, Palomar García V. Significación clínica de la asimetría amigdalina. Acta Otorrinolaringol Esp. 2009;60:194-8.

11. Hwang MS, Kaye KE, Waxman JA, Friedman M. What is the best management of asymptomatic unilateral tonsillar enlargement? Laryngoscope. 2015;125:2438-40.

12. Kutluhan A, Salvız M, Yalçıner G, Kandemir O, Yeşil C. The role of the Actinomyces in obstructive tonsillar hypertrophy and recurrent tonsillitis in pediatric population. Int J Pediatr Otorhinolaryngol. 2011;75:391-4.

13. Bhargava D, Bhusnurmath B, Sundaram KR, Raman R, Al Okbi HM, Al-Abri R, et al. Tonsillar actinomycosis: a clinicopathological study. Acta Trop. 2001;80:163-8.

14. Wojtera M, Paradis J, Husein M, Nichols AC, Barret JW, Salvadori MI, et al. The prevalence of human papillomavirus in pediatric tonsils: a systematic review of the literature. J Otolaryngol Head Neck Surg. 2018;47:8.

15. Syrjänen S. HPV infections and tonsilar carcinoma. J Clin Pathol. 2004;57:449-55.

16. Grant MC, Raggio B, Barton B, Guarisco JL. Establishing the need for an evidence-based treatment algorithm for peritonsillar abscess in children. Clin Pediatr (Phila). 2018;57:1385-90.

17. González YI, Nazar MG, Callejas CC, Arredondo AM, Nilsen VE. Tumores amigdalinos: aspectos clínicos e histopatológicos. Rev Otorrinolaringol Cir Cabeza Cuello. 2004;64:223-9.

18. Siupšinskienė N, Padervinskis E, Poškienè L, Endeley N, Vaitkus S. An unusual case of a sore throat and otalgia in a 4-year-old boy. Medicina (Kaunas). 2012;48:277-9. 